\title{
Stage II Nasopharyngeal Carcinoma AJCC v6
}

National Cancer Institute

\section{Source}

National Cancer Institute. Stage II Nasopharyngeal Carcinoma A/CC v6. NCI Thesaurus. Code C7920.

Stage II includes: IIA (T2a, N0, M0); IIB (T1, N1, M0), (T2, N1, M0), (T2a, N1, M0); (T2b, NO, M0); (T2b, N0, M0); (T2b, N1, M0). T2: Tumor extends to soft tissues. T2a: Tumor extends to the oropharynx and/or nasal cavity without parapharyngeal extension. T2b: Any tumor with parapharyngeal extension. N1: Unilateral metastasis in lymph node(s), 6 $\mathrm{cm}$ or less in greatest dimension, above the supraclavicular fossa. M0: No distant metastasis. (AJCC 6th ed.) 